\title{
REFORMASI PROTESTAN DAN PERANG AGAMA PERANCIS
}

\author{
Oleh: \\ Nugroho \\ nugroho_uin@radenfatah.ac.id
}

\begin{abstract}
Protestant Reformation emerged in the 16th century in Europe caused economic factors, politics, nationalism, individualism, renaissance, as well as the practice of indulgences. This study is library research and analyzed with descriptive analytic. Protestant Reformation led to divisions and wars in Christianity that is so terrible that resulted in the sacrifice of life. Resolutions taken the result of the reform protestanya The Peace of Westphalia.
\end{abstract}

Key word:(reformation,wars, peace).

\begin{abstract}
Abstrak
Reformasi Protestan muncul pada abad ke-16 di Eropa yang disebabkan faktor ekonomi, politik, nasionalisme, individualisme, kebangkitan, serta praktik indulgensi. Penelitian ini adalah perpustakaan penelitian yang dianalisis secara deskriptif analitik. Reformasi Protestan menyebabkan perpecahan dan perang dalam agama Kristen yang begitu mengerikan yang mengakibatkan pengorbanan hidup. Resolusi diambil hasil reformasi protestan The Peace of Westphalia.
\end{abstract}

Kata Kunci: reformasi, perang, perdamaian

\section{A. Pendahuluan}

Masa reformasi merupakan salah satu gerakan besar yang mulai bergulir di seluruh "Dunia Kristen" di Eropa pada abad awal abad ke 16, yang muncul bersamaan dengan bermacam-macam gerakan yang di motori oleh kelas menengah Eropa yang muncul untuk melakukan pembaharuan, gerakan yang menunjang gerakan reformasi Grejawi antara lain gerakan renainsans, pencerhan, gerakan humanis, gerakan yang mengarah kepada emanisipasi rakyat, dan gerakan untuk mencari format baru dalam bidang kebudayaan, pembaharuan pemikiran teologi dan 
struktur Gereja, perkembangn ilmu pengetahuan dan kehidupan sosial politik, serta munculnya nasionalisme dari bangsa-bangsa di Eropa yang sadar akan hegemoni kekuasaan Roma dan identitas mereka sendiri selaku bangsa. ${ }^{1}$

Pada abad ke-16 satu abad setelah berlangsungnya era pencerahan di dunia ilmu yang pada hakikatnya pembebasan akal dan dari kecendrungan dogmatisme (Gereja) dalam bidang keagamaan respon terhadap otoritas Paus di Vatikan mulai bermunculan yang dipelopori oleh Awingli (1484-1531), Marthin Luther (1483-1546) dan John Calvin (1509-1564). ${ }^{2}$

Perbedaan agama telah menyulut beberapa konflik bahkan peperangan antar agama yang paling brutal dalam sejarah manusia. Seringkali perbedaan-perbedaan kecil dalam ajaran agama dapat menyebabkan terjadinya peperangan dan bahkan membenarkan pembantaian manusia secara massal, yang ironisnya atas nama Tuhan dan panggilan suci agama. ${ }^{3} \mathrm{Hal}$ ini pun terjadi dengan bersamaan adanya reformasi di Eropa yang mana pada saat itu tidak luput dari konflik kepentingan yang menyebabkan perpecahan dan peperangan serta korban jiwa yang disebabkan perselisihan antar manusia dan pandangan terhadap ajaran agama yang berbeda (perang mengatas namakan Tuhan) pada saat itu tidak dapat dilupakan begitu saja dalam fakta sejarah agama Kristen.

Dengan adanya persoalan di atas penulis dalam makalah ini akan membahas mengenai defenisi dan sejarah the protestant reformation, penyebab the protestant reformation, konflik (wars) yang terjadi serta resolusi konflik yang pernah ditawarkan pada waktu reformasi Protestan dan perang agama di Prancis.

\section{B. Pengertian dan Sejarah The Protestant Reformation and French Wars of Religion}

Reformasi Protestan adalah sebuah gerakan yang timbul di abad ke-16 sebagai suatu rangkaian upaya untuk melakukan pembaruan terhadap Gereja Katolik Roma di Eropa Barat. Reformasi utama dimulai oleh Martin Luther dan 95 dalilnya. Reformasi ini berakhir dengan pembagian dan pendirian institusi-institusi baru, di antaranya Gereja Lutheran, Gereja-gereja Reformasi, dan Anabaptis.

\footnotetext{
${ }^{1}$ Th. Sumartana, Sekelumit Sejarah Gereja Protestan, dalam Sejarah, Teologi dan Etika Agama-agama, (Yogyakarta: Interfidei, 2003), hlm. 69-70.

2 Bahri Ghazali, Agama Masyarakat: Pengenalan Sejarah Agama-agama, (Yogyakarta: Pustaka Fahima, 2005), hlm.139

${ }^{3}$ Rodney Stark, One True God, terj. M.Sadat Ismail, (Yogyakarta: Qalam, 2003), hlm. 169.
} 
Gerakan ini juga menimbulkan Reformasi Katolik di dalam Gereja Katolik Roma. Rancangan teologis dan latar belakangnya disusun pada Konsili Trente (15481563), ketika Roma memukul balik gagasan-gagasan fundamental yang dibela oleh para Reformator, seperti Luther. ${ }^{4}$

Istilah "Protestan" berasal dari hasil persidangan umum ke dua di Speyer (Februari 1529) yang memutuskan untuk mengakhiri toleransi terhadap lutheranisme di Jerman. Dalam bulan April tahun itu juga, enam pangeran Jerman dan empat belas kota memprotes tindakan itu. Mereka mempertahankan kemerdekaan hati nurani dan hak-hak dari minoritas keagamaan. Istilah "Protestan" berasal dari tindakan ini. karena itu, adalah tidak benar untuk menerapkan istilah "Protestan" kepada individu-individu yang bergerak sebelum bulan April 1529 atau untuk berbicara mengenai peristiwa-peristiwa sebelum tanggal sebagai yang membentuk "Reformasi Protestan". 5

The frence wars of religion adalah peperangan yang terjadi antara katolik dan protestan yang melibatkan 16 negara yang dimulai tahun 1562 dan berakhir pada tahun $1598 .^{6}$

Ada empat unsur yang terdapat dalam defenisi tentang reformasi yaitu: ${ }^{7}$

\section{Lutheranisme atau Reformasi Luther}

Reformasi Luther secara khusus dikaitkan dengan wilayah-wilayah Jerman di bawah pengaruh pribadi yang mendalam dari seorang yang berkharisma-Martin Luther. Reformasi Luther pada mulanya berbentuk reformasi akademis terutama berkenaan dengan pembaharuan pengajaran teologi di Universitas Wittenberg. Dalam hal ini Luther memasang 95 tesis yang terkenal (31 Oktober 1517) dan berdebatan Leipzing (Juni-Juli1519) dan ini menimbulkan gelombang-gelombang dan ide-idenya semakin meluas keluar dari Wittenberg. Martin Luther secara khusus memperhatikan masalah doktrin pembenaran, yang merupakan pokok utama dari pemikiran keagamaan.

\section{Gereja Reformed}

\footnotetext{
${ }^{4}$ www. reformasi protestan. Com di download tanggal 20 maret 2009.

5 Alister E.Macgrath, Reformation Thought: An Introduction, Published by Blackwell Publishers, 1993, terj tim PT BPK Gunung Mulia, Jakarta, 1996, hlm. 7-8.

${ }^{6}$ Djama'annuri, handout matakuliah Sejarah Konflik dan Perdamaian Agama-agama, pada tanggal 2 April 2009.

${ }^{7}$ Alister E.Macgrath, Reformation Thought: An Introduction.....hlm, 7-14.
} 
Asal usul Gereja reformed terletak di dalam perkembangan-perkembangan yang terjadi di negara konfederasi Swiss. Gereja reformed berakar pada serangkaian usaha membaharui moral dan peribadahan Gereja (tanpa mementingkan ajarannya) agar lebih sesuai dengan pola yang terdapat dalam alkitab. Tokoh Gereja reformed ini adalah Zwingli, meskipun latar belakangnya akademis tapi pembaharuannya pada hakikatnya bukan akademis. Program-program nya diarahkan ke Gereja sebagaimana yang ada di kota-kota Swis, seperti Zurich, Bern dan Basel.

Konsolidasi Gereja reformed umumnya dipandang berawal bersamaan dengan stabilitas dari reformasi di Zurich (setelah kematian Zwingli dalam pertempuran 1531) di bawah penggantinya Heinrich Bullinger, dan berakhir dengan munculnya Jenewa sebagai basis kekuatannya.

\section{Reformasi Radikal (Anababtis)}

Istilah "Anababtis" mempunyai asal usulnya pada Zwingli (kata"anababtis" secara harfiah berarti orang-orang yang dibabtis kembali dan ini merujuk pada aspek yang paling khas dari kebiasaan orang-orang Anababtis, pendirian yang kokoh bahwa hanya orang yang telah melakukan pengakuan iman pribadi di hadapan umum yang boleh dibabtis). Anababtisme pertama kali muncul di sekitar Zurich, yakni setelah reformasi Zwingli di dalam kota pada awal dekade 1520-an. Meskipun anababtis muncul di Jerman dan Swis. Namun gerakan ini berpengaruh sampai ke Belanda.

\section{Reformasi Katolik}

Istilah "Reformasi Katolik" sering dipakai untuk merujuk pada revitalisasi dari katolisisme Roma dalam priode setelah pembukaan konsili trente (1545). Dalam karya-karya kesarjanaan yang terlebih dahulu, gerakan ini sering digambarkan sebagai "kontra reformasi". Gerakan itu merupakan suatu reformasi dari Gereja Katolik Roma sekaligus reaksi terhadap Reformasi Protestan.

Pada kounter reformasi ini Paus Leo X mengiginkan Martin Luther mencabut pernyataannya yang terdapat dalam 95 tesisnya dan Mrtin Luther sendiri menolak, kaunter reformasi ini dilakukan sebelum adanya pertemuan antara pemimpin gereja katolik. $^{8}$

\footnotetext{
${ }^{8}$ Djama'annuri, handout matakuliah Sejarah Konflik dan Perdamaian Agama-agama, pada tanggal 2
} April 2009. 
Pada awal abad ke 16 adalah awal berlangsungnya reformasi Protestan dimana pada abad ini Gereja di Eropa Barat berada dalam keadaan yang sangat memerlukan pembaharuan. Tata Gereja yang resmi benar-benar membutuhkan pembongkaran yang menyeluruh dan birokrasi kegerejaan telah menjadi sangat tidak efisien dan korup, moral para rohaniawan sering tampak lemah dan menjadi sumber sekandal bagi jemaat mereka, para petinggi rohaniawan sering tidak ada di tempatditengah jamaat. Uskup agung dari Sens, Antoine Du Prat, seorang Prancis, muncul hanya sekali dalam upacara ibadah di Katredal. Sebagian besar jabatan kegerejaan yang tinggi di peroleh melalui cara-cara yang tidak di pertanggungjawabkan, umumnya di dasarkan atas hubungan keluarga, status politik atau setatus keuangan bukan atas kualitas kerohanian mereka. Seperti halnya Duke Amadeus dari Savoy mengamankan pengangkatan anaknya sebagai uskup senior di Jenewa pada tahun 1451 walaupun masih berumur delapan tahun. Paus Alexander VI, seorang anggota borgia memastiakn pemilihan kepausan dalam tahun 1492 meskipun mempunyai beberapa selir dan tujuh orang anak mereka membeli kepausan yang palsu tanpa pengetahuan dari saingan-saingan terdekatnya. ${ }^{9}$

Persoalan praktek indulgensi terjadi di Gereja. Indulgensi adalah sarana yang digunakan Gereja untuk memungkinkan orang menghindari hukuman tertentu atas dosa-dosa mereka kalau seseorang tidak mendapatkan indulgensi, hukuman akan dilaksanakan di api pencucian setelah kematian. Untuk memperoleh indulgensi, disamping silih rohani tertentu, orang harus membayar sejumlah uang yang akan menjamin kebebasan mereka dari hukuman dari api pencucian orang sangat tertarik untuk membayar sejumlah uang kepada Gereja agar memperoleh kebebasan dari hukuman di api pencucian, dan Gereja memperoleh penghasilan yang sangat besar dari penjualan indulgensi tersebut. ${ }^{10}$

Di Prancis pejabat Gereja menikmati pembebasan sebagian besar pajakpajak. Ke Uskupan dari Meaux di Prancis yang merupakan pusat aktivis-aktivis pembaruan pada priode 1521-1546 pejabat Gereja dibebaskan dari pajak pengasramaan serta pembekalan pasukan tentara inilah yang menyebabkan kebencian masarakat karena hal ini dilakukan karena dalam masa-masa kesulitan

\footnotetext{
${ }^{9}$ Alister E.Macgrath, Reformation Thought: An Introduction.....hlm 2-3.

${ }^{10}$ H. Byron Earhart, Religious Tradisions Of The Word: A Journey Through Africa, Nort America, Mesoamerica, Judalsm, Crhristianity, Hinduism, Buddhism, China And Japan, Hipersan Francisco. 1993. hlm 522.
} 
ekonomi. Kemudian di keuskupan Rouen terjadi huru hara di kalangan rakyat tentang keuntungan yang tidak disangka-sangka yang diperoleh Gereja dengan menjual gandum pada priode paceklik yang parah pada tahun 1520 -an. ${ }^{11}$

Pada masa ini golongan gereja dan bangsawan memilki hak-hak istimewa. Golongan gereja ini terdiri dari semua pelayan gereja Katolik, baik yang masuk dalam ordo-ordo keagamaan maupun yang tidak semuanya ini ikut menkmati hakhak istimewa yang dipunyai Agama Negara, yaitu kehormatan, kekayaan dan kemerdekaan. Pembebasan fiscal adalah hak, golongan Gereja hanya harus memberikan "hadiah gratis") kepada seorang pangeran dan jumlah uang dan kenaikan jumlahnya ditentukan dan dikumpulkan sendiri oleh pangeran. Sedangkan kaum bangsawan adalah kaum ningrat mereka merupakan zona konsentrasi semua hak-hak istimewa diantaranya bangku di gereja khusus, monopoli-monopoli seperti perburuan, pajak-pajak dan hak-hak lain. Pada intinya " hidup layaknya seorang bangsawan "adalah cita-cita masyarakat prancis. ${ }^{12}$

Golongan yang mendapat hak istimewa adalah golongan gereja proritas ini disebabkan fungsinya yang bersifat keramat dan sekaligus karena peranannya dlam negra. Agama katolik adalah agama Negara sehingga seluruh rakyat Raja Prancis adalah Ktolik. Gereja mempunyai otonomi ganda dalam hubungannya dengan Raja Prancis dan Roma dan golongan ini sering mengadakan pertemuan dan mencoba memecahkan persoalan fiscal dan perlindungan agama dengan pengadilanpengadilan istimewa, yaitu hakim-hakim gereja kekutan ekonomi golongan gereja sangat besar mereka dibebaskan dari pajak dank arena hadiah geratis yang disetujuinya golongan gereja juga mendapat bagian sepersepuluh dari hasil bumi dari petani. ${ }^{13}$

Dengan kondisi Gereja pada abad ke-16 maka mendorong adanya jeritan pembaharuan untuk reformasi Gereja dalam bidang administrasi, moral, hukum: penyalah gunaan dan immoralitas harus disingkirkan, Paus harus mengurangi masalah-masalah duniawi, administrative Gereja harus disederhanakan dan dibersihkan dari korupsi. Kemudian adanya tuntutan akan perlunya reformasi atas ajaran teologi dan paham-paham agama Kristen. Bagi pengamat kritis seperti Martin

\footnotetext{
${ }^{11}$ Alister E.Macgrath, Reformation Thought: An Introduction.....hlm. 35. 19-30.

12 Francois Furet dan Denis Richet, French Revolution, terj. Team Penerjemah Lembaga Indonesia Prancis, (Yogyakarta: Gajah Mada University Press, 1989) hlm. 18-20.

${ }^{13}$ Francois Furet dan Denis Richet, French Revolution, hlm. 21.
} 
Luther dari Wettenberg dan Yohanes Calvin dari Jenewa, Gereja telah kehilangan akan identitas intelektualnya. Dan mereka berpendapat waktunya memperoleh kembali dari zaman keemasan Gereja, menurutnya keadanan yang menyedihkan pada abad ke 16 adalah suatu penyelewengan dari paham-paham yang utama dan khas dari imam Kristen menurut dia kekristenan tidak dapat diperbaharui tanpa suatu pemahaman akan arti sebenarnya akan kekristenan itu. Paham-paham dasar yang utama telah diputar balikkan dan kabur oleh para pemuka Gereja pada saat itu. ${ }^{14}$

Perpaduan Gereja dan negara yang berkembang dalam Imperium Romawi Suci dalam perjalanannya telah menghasilkan sejumlah skandal kekuasaan. Lembaga Gereja rusak sebab ia terlibat dalam manuver dan perebutan kekuasaan duniawi. Banyak perilaku para Paus dan Kardinal sama sekali tidak mencerminkan gambaran "orang suci", bahkan banyak di antara mereka hidup royal dalam gemerlap kesenangan duniawi. Pemandangan ini menggusarkan banyak orang dan puncaknya terjadi dalam gerakan Reformasi Protestan yang dimotori Luther. Ide-ide Reformasi sebenarnya bukan hal baru. Sebelum Luther, gagasan-gagasan reformis telah dilambungkan oleh para teolog dan intelektual seperti John Wycliff (1320-84), John Huss (1369-1415), Erasmus (1467-1536) dan Sir Thomas More (1478-1535). ${ }^{15}$

Namun, di tangan Luther, gagasan-gagasan reformasi telah menjadi bara api yang menghanguskan Eropa dalam huru-hara besar. Dengan temperamen pribadi yang melekat padanya, Luther telah menjadikan gerakan Reformasi sebagai pangkal tolak tersusun ulangnya peta Eropa, tersemainya paham nasionalisme. Negara modern lahir dari rahim sejarah Eropa yang letih berperang saudara selama tiga puluh tahun. Perang bermula ketika Luther melancarkan gerakan potes terhadap berbagai skandal politik-agama dalam Imperium Romawi Suci (Holy Roman Empire). Setelah memakukan '95 tesis' hebohnya di pintu kapel Gereja Wittenberg pada 1517, gagasan-gagasan Luther segera menjalar ke berbagai kota yang kemudian dikenal sebagai "Protesting Estates" (Wilayah-wilayah Pemrotes) dan mereka yang meninggalkan Gereja Roma selanjutnya disebut dengan kaum "Protestan". ${ }^{16}$

Gerakan reformasi mulai memuncak ketika adanya penolakan terhadap otoritas paus sebagai pemimpin tertinggi di Gereja Katolik sekaligus orang suci (The

\footnotetext{
${ }^{14}$ Alister E.Macgrath, Reformation Thought: An Introduction.....hlm 3-4

15 Lihat Lee Cameron Mc Donald, Western Political Theory, Vol II (New York: Harcourt Brace Javanovich, 1969), Hlm. 26-220

${ }^{16}$ Edith Simon, The Reformation. (New York: Time-Life Books, 1966).
} 
Saint) di Vatikan (Roma), akibat dari protes para reformer ini melahirkan adanya tiga gerakan agama yaitu Katolik yang berpusat di Vatikan, Protestan tersebar di wilayah Inggris dan Belanda, Kristen Gereja Ortodoks (dulu uni Soviet). ${ }^{17}$

Luther membuka permasalahan indulgensi dengan sembilan puluh lima tesisnya. Tesis tersebut di kirimnya pada tanggal 31 Oktober 1517 kepada Uskup Agung Albert dari Mainz dan kepada beberapa orang, dan juga ia menempelkan pada pintu-pintu Gereja Puri di Wittenberg. ${ }^{18}$

Menurut Martin Luther, anugerah hanya boleh didefinisikan dan menjadi jelas dalam satu kalimat, yaitu pengampunan dosa. Anugrah sama dengan pengampunan dosa. Oleh Karena itu tidak seharusnya anugerah yang berupa pengampunan dosa di beli dengan uang untuk memperoleh karcis pengampunan dosa. Martin Luther melakukan protes terhadap para pemimpin Gereja yang telah menjual surat pengampunan dosa. Selain martin Luther Calvin dan Zwingli, juga merupakan tokoh reformasi yang berpandangan bahwa Allah akan memberikan dengan cuma-cuma pengampunan dosa, memberikan peranakan, dan memberikan pembenaran kepada manusia yang berdosa. ${ }^{19}$

Para reformer juga menekankan mengenai iman kepercayaan. Iman kepercayaan bukan semacam pengakuan intelektual saja terhadap doktrin yang dipaksakan. Juga bukan semacam pengertian ajaran yang hanya bersifat rasionil saja, tetapi iman bagi Luther adalah suatu penerimaan-atas-penerimaan( the acceptance of the acceptance). Yang dipertahankan oleh para reformer adalah konsep bahwa iman adalah sesuatu penyerahan total dihadapan anugerah Allah

${ }^{17}$ Perbedaan agama Khatolik dengan yang lain yaitu pembabtisan dilakukan sejak anak dilahirkan, terdiri satu gereja dalam artian gereja Vatikan merupakan sebagai sentralnya, gereja bertingkat(hirarchis) dengan pimpinan tertinggi Paus sedangkan di Negara lain adalah perwakilan dipimpin oleh uskup sebagai wakil paus, Paus adalah perwujudan Yesus dalam bentuk kongkrit dan ia adalah Rasul penerus petrus, Pastur tidak boleh menikah, penghimpunan dosa hanya dilakukan oleh Paus, interpretasi alkitab hanya oleh Paus atau gereja sebagai penentu dogma, sakramen berjumlah tujuh buah melalui gereja, masyarakat adalah masyarakat gereja.

Sedangkan yang membedakan agama ini adalah pembabtisan dilaksanakan setelah anak dewasa, gereja adalah sama tidak ada pimpinan tertinggi, pastur boleh menikah, pengampunan boleh dilaksanakan dimana saja dan itu hak semua orang, interpretasi alkitab boleh dilakukan oleh siapa saja, masyarakat adalah masyarakat sekte(bidat), sakramen hanya dua macam, penjamuan suci, roti dan anggur hanya sekedar mengenang sejarah perjalanan Yesus tidak benar-benar terjadi.

Yang membedakan Kristen Ortodok Timur adalah kekuasaan Gereja di timur lebih sedikit, interpretasi diserahkan pada perseorangan, Paus di Gereja timur berperan terbatas, sebab kekuasaan ilahi diungkap dengan hati nurani, semua umat Kristen itu adalah satu, tidak ada tingkatan gereja, kehidupan mistik lebih ditekankan sesuaidengan kondisi timur, tidak ada konsep membujang dalam Bahri Ghazali, Agama Masyarakat: Pengenalan Sejarah Agama-agama, (Yogyakarta: Pustaka Fahima, 2005), hlm.139-140.

18 Hans-Peter Grosshans, Luther, terj p. Hardono Hadi, (Yogyakarta: Kanisius, 2001), hlm. 35

19 Stephen Tong, Reformasion And Teologi Reformer, tej. Ahmad suadi,(Jakarta: Taman Pustaka Kristen, 1991), hlm. 27.S 
yang menghentikan segala pergumulan atau penyadaran kepada diri yang tidak layak, sebaliknya melihat Allah yang melayakkan kita. ${ }^{20}$

Para reformer mengingatkan kembali seperti ajaran mengenai system pertobatan dan pengakuan dosa yang dijalankan oleh orang katolik atau dalam Gereja katolik, suatu sistim mengenai pengakuan dosa yang dilaksanakan di hadapan pastor kemudian menerima pengampunan. Para reformer juga menolak mengenai ajaran intermediate state (suatu keadaan antara sesudah kematian dan sebelum kebangkitan orang mati, dimana pada ajaran ini, Katolik mengajarkan adanya api penyucian (purgatory) para reformer berpandangan ajaran ini tidak sesuai dengan alkitab. ${ }^{21}$

Prinsip penting teologi reformasi ada empat prinsip yaitu ${ }^{22}$ Sola Gratia, hanya berdasarkan anugrah saja. Prinsip ini menolak segala jasa manusia. Menolak pandangan mengenai adanya kerjasama antara manusia dan Allah untuk menyelamatkan manusia. Sola Fide, artinya hanya berdasarkan iman kepercayaan saja manusia diterima oleh Allah, dan dapat datang pada Tuhan. Sola Scriptura, hanya percaya kepada apa yang dikatakan oleh Alkitab itu adalah firman Allah. Sola Cristos, berarti hanyalah bagi Kristus menjadi pusat seluruh Alkitab. Maka tidak ada seorangpun di dalam duni ini yang boleh dibandingkan atau disetarakan dengan kedudukan Kristus. Paus, orang suci, Maria atau siapapun tidak dapat disetarakan dengan Kristus.

\section{Penyebab Reformasi Protestan dan Perang Agama Perancis}

Sebab-sebab perpecahan agama Roma Katolik dan timbulnya apa yang kemudian disebut sebagai agama Protestan sungguh sangat ruwet dan masih diberdebatkan. Menurut Huston Smith, faktor ekonomi, politik, nasionalisme, paham individualisme renaisans, dan keprihatinan yang sangat meningkat terhadap penyalah gunaan wewenang Gereja, merupakan faktor penting yang mempunyai pranan dalam reformasi Protestan. Namun hal-hal itu tidak menutup kenyataan

\footnotetext{
${ }^{20}$ Stephen Tong, Reformasion And Teologi Reformer.......hlm. 28-29.

${ }^{21}$ Stephen Tong, Reformasion And Teologi Reformer........hlm. 36.

${ }^{22}$ Stephen Tong, Reformasion And Teologi Reformer.......hlm. 39-40.
} 
bahwa penyebabnya yang mendasar bersifat keagamaan, yaitu adanya perbedaan pendapat antara agama Roma Katolik dan agama Protestan. ${ }^{23}$

Reformasi Protestan juga disebabkan adanya peristiwa pada tahun 1517 Johann Tetzel menjual ablass briefe indulgence (surat pengampunan hukuman temporal dari dosa) dari paus Leo X (1513-1521) guna untuk mengumpulkan uang bagi perbaikan Greja st. Peter di Roma. Dalam hal ini orang-orang yang memberi sumbangan uang, dan mengakui dosanya dijanjikan pengampunan dari hukuman di dunia, maka Marthin Luther menyerang tindakan Tetsel dengan menempel 95 artikel (theses) pada pintu Gereja Wilzenberg (31 oktober 1517) lebih lanjut lagi Luther juga tidak mengakui supremasi Paus. Luther menulis pamlet antara lain an address to the Christian nobility of the german nation. ${ }^{24}$

Krisis kewibawaan adalah faktor penyebab adanya reformasi Protestan karena pada saat itu kewibawaan dari Paus dipersoalkan skisma besar dan akibatakibatnya. Skisma besar (1378-1417) membawa pada perpecahan kekristenan di Barat, tepatnya pada saat kematian Gregorius XI. Golongan Italia dipimpin oleh Urbanus VI, dan Golongan Prancis dipimpin oleh Clement VII. Situasi tersebut berlanjut sampai 1417 ketika konsili Constance (1414-1417) memilih Martin V sebagai Paus. Untuk satu priode yang singkat sekitar tahun 1409 terdapat pihak yang mengklaim kepausan. ${ }^{25}$

\section{Konflik dan Resolusi Konflik Pada Waktu Reformasi Protestan Terjadi dan Peperangan di Perancis.}

Pembaruan yang dilakukan oleh Luther, Zwingli dan Calvin mencerminkan perubahan-perubahan dengan meninggalkan ajaran Katolik Roma, mereka membuat etos baru yang memuat otonomi baru dan kebebasan total yang membuat individu harus dibebaskan dalam membaca dan menafsirkan alkitab tanpa control Gereja yang bersifat menghukum. Terkadang mereka menengok nilai-nilai ekstrim dan bahkan nilai kekerasan supaya agama mereka dapat menjawab kondisi dunia yang mengalami perubahan radikal. Dalam usaha memuluskan tuntutannya para pembaharu bersikap tanpa kompromi terhadap setiap orang yang menyanggah

\footnotetext{
${ }^{23}$ Huston Smith, The Religions of Man, Perennial Library, Haper \& Row, Publisher, New York, Hargestown, San Francisco, London, tt, Terj, Saafroedin Bahar, (Jakarta: Yayasan Obor, 2004, hlm. 403.

24 Marwati Djoened Poesponegoro, Tokoh dan Peristiwa dalam Sejarah Eropa Awal Masehi1815,(Jakarta: UI.Press, 1998), hlm. 199.

${ }^{25}$ Alister E.Macgrath, Reformation Thought: An Introduction.....hlm...43-44.
} 
ajaran mereka, Luther menyatakan bahwa buku-buku "kafir" harus dibakar, dan Calvin serta Zwingli tidak segan-segan membunuh para pembangkang. ${ }^{26}$

Reformasi merupakan peristiwa mengerikan, karena mampu membelah Eropa menjadi kubu-kubu yang saling bermusuhan. Di Inggris, kaum Protestan dan Katolik saling membantai satu sama lain. Kemudian di Prancis terjadi perang saudara antara Protestan dan Katolik ( 1562-1598). _Konflik tersebut dimulai dari pertengahan abad 16 dan diakhiri keluarnya maklumat Nantes tahun 1598. Peperangan ini meliputi peperangan sipil dan juga operasi militer. Di samping unsur-unsur agama, peperangan tersebut merupakan perjuangan terhadap kontrol yang berlebihan akan aturan-aturan negara antara kekuasaan House of Guise (Lorraine) dan Liga Katolik di satu sisi dengan House of Bourbon di sisi lain. Peperangan ini juga dianggap sebagai perang antara Raja Philip II dari Spanyol dan Ratu Elizabeth I dari Inggris. Perang ini diakhiri dengan dikeluarkannya maklumat Nantes oleh Henry IV, Raja Perancis yang memberikan toleransi keagaamaan pada Protestan. ${ }^{27}$

Kemudian pembantaian kaum Protestan secara besar-besaran pada tahun 1572. Perang tiga puluh tahun (1618-1648) meluluh lantahkan bangsa-bangsa Eropa satu demi satu, suatu pertarungan politik bernuansa religius yang memusnahkan impian satu Eropa. ${ }^{28}$ Perang Tiga Puluh Tahun melibatkan segitiga kekuatan. Segi pertama, perang tersebut merupakan perang saudara antara orang Jerman Protestan dan orang Jerman Katolik. Segi kedua, perang ini merupakan perang saudara yang dilakukan oleh para pangeran Jerman dari kedua aliran agama melawan Kaisar mereka. Dan segi ketiga, perang ini merupakan perang internasional: Perancis menentang wangsa Habsburg, orang Spanyol berusaha mendapatkan kembali kekuasaannya atas Belanda, dan orang Skandinavia yang baru bangkit berusaha mendapatkan bagian di benua Eropa, dan bangsa-bangsa yang berdiri di pinggir medan laga membantu salah satu pihak yang berperang dengan uang, tentara dan perjanjian, terkadang membela satu pihak dan terkadang membantu pihak lain. Dalam pertempuran yang bersegi banyak ini, pasukan dari enam kebangsaan terlibat secara aktif: Jerman, Spanyol, Perancis, Denmark, dan Swedia. Yang lain, yakni Inggris, Polandia, Skotlandia dan Transylvania,

\footnotetext{
${ }^{26}$ Karen Armstrong, The Battle For God, (New York: Alfred A. Knopf, 2000), terj. Satriowahono dkk. hlm. 100-101.

${ }^{27} \mathrm{http}: / /$ perang-saudara-seagama-di-prancis di download tanggal 231 pril 2009.

${ }^{28}$ Karen Armstrong, The Battle For God.....116.
} 
menyediakan pasukan bayaran yang anggotanya terdiri dari orang-orang Yunani, Turki, Italia, dan Belanda.

Reformasi Protestan telah menghanguskan Eropa. Secara rinci, Bainton mencatat beberapa dampak Gerakan Reformasi Protestan. Tanpa seluruhnya mengafirmasi dampak ini sebagai akibat logis dari gerakan Reformasi, Bainton mencatat beberapa akibat yang paling tidak dipicu oleh gerakan Reformasi ini. ${ }^{29}$ Pertama, perpecahan di dalam agama Kristen. Perpecahan ini telah memperlemah struktur agama Kristen yang telah terbangun selama tiga ratusan tahun. Perpecahan ini juga mengakibatkan perang saudara yang membumi-hanguskan Eropa. Kedua, Reformasi Protestan memiliki dampak sosial, di antaranya adalah lahirnya nasionalisme dan demokrasi. Nasionalisme mencakup nasionalisme kultural dan nasionalisme politik. Sementara demokrasi meliputi doktrin tentang kedaulatan terbatas negara, hak-hak perorangan, pemerintahan perwakilan, hak suara universal, pemisahan Gereja dengan negara, kebebasan beragama, dan pendidikan rakyat. Ketiga, Reformasi Protestan memiliki dampak ekonomi, di antaranya, kaum Protestan-terutama Kalvinisme-telah menghembuskan andil yang tidak sedikit kepada spirit kapitalisme. Keempat, gerakan reformasi mendorong gelombang perkawinan dan menjauhi laku selibat sebagaimana lazim dalam tradisi kerahiban Katolik. Gejala ini membentuk kultur yang turut mewarnai wajah peradaban Eropa dikemudian hari. Last but not least, dampak yang tidak kalah penting adalah bahwa Reformasi Protestan telah merobohkan klaim universalitas kedaulatan Gereja dan Paus yang pada urutannya mempersiapkan landasan bagi era absolutisme sekuler.

Pada tahun 1540-an dan awal tahun 1550-an Jerman berada dalam keadaan tidak setabil, disebabkan adanya konflik antara golongan Luteran dan Roma katolik dan konflik itu sampai meruntuhkan kekaisaran pada saat itu ada perdamaian Augsburg (September 1555) berusaha menyelesaikan masalah keagamaan di Jerman dengan mengalokasikan daerah-daerah tertentu kepada golongan luteran dan sisanya kepada golongan Roma Katolik, prinsip terkenal yang sering digunakan untuk menyelesaikan persoalan itu adalah cuius region, eius religio (wilayahmu menentukan agama mu). ${ }^{30}$ 
Eropa pada abad pertengahan dilanda perang yang hebat, perang ini berlangsung selama kurang lebih tiga puluh tahun (1618-1648). Perang ini disebabkan pertentangan antara kaum Protestan dan kaum Katolik (dimulai oleh Reformasi Protestan sampai pada kontra Reformasi Katolik) dan disamping aspek agama ini juga persaingan dinasti Hapsbruk dan Boubron. Setelah didera keletihan dan kehancuran besar, akhirnya perang terhenti melalui PerjanjianWestphalia pada tahun 1648 di tanda tangani di Westphalen, Jerman., selanjutnya dikenal dengan Perdamaian Westphalia (The Peace of Westphalia). ${ }^{31}$

Perjajian tersebut dapat dikatakan telah mensyahkan suatu sistim negara bangsa karana telah mengakui, bahwa Empire (gereja,kerajaan-kerajaan) tidak dapat lagi memaksakan kehendaknya kepada negara-negara bagiannya atau wilayahnya. Akan tetapi dapat dilakukan apabila daerah-daerah tersebut mau mengakui atau bergabung dengan Empire-empire tersebut. Bahkan di perjanjian inipun Sri Pauspun dibatasi kekuasaannya

Perdamaian Westphalia dianggap sebagai peristiwa penting dalam sejarah Hukum Internasional modern, bahkan dianggap sebagai suatu peristiwa Hukum Internasional modern yang didasarkan atas negara-negara nasional. Sebabnya adalah : ${ }^{32}$ (1) Selain mengakhiri perang 30 tahun, Perjanjian Westphalia telah meneguhkan perubahan dalam peta bumi politik yang telah terjadi karena perang itu di Eropa . (2) Perjanjian perdamaian mengakhiri untuk selama-lamanya usaha Kaisar Romawi yang suci. (3) Hubungan antara negara-negara dilepaskan dari persoalan hubungan kegerejaan dan didasarkan atas kepentingan nasional negara itu masingmasing. (4) Kemerdekaan negara Nederland, Swiss dan negara-negara kecil di Jerman diakui dalam Perjanjian Westphalia. Perjanjian Westphalia meletakan dasar bagi

susunan masyarakat Internasional yang baru, baik mengenai bentuknya yaitu didasarkan atas negara-negara nasional (tidak lagi didasarkan atas kerajaan-kerajaan)

Kung, Theologi For The Third Millennium An Ecumenical View, translated by Peter Heinegg, united States Of America, 1988. 17.

31 lihat Charles Blitzer, Age of Kings (New York: Time Incorporated, 1967).

32 http://perjanjian-westphalia-dan-munculnya-negara-bangsa/ di download tanggal 23 april 2009. 
maupun mengenai hakekat negara itu dan pemerintahannya yakni pemisahan kekuasaan negara dan pemerintahan dari pengaruh gereja.

Dasar-dasar yang diletakkan dalam Perjanjian Westphalia diperteguh dalam Perjanjian Utrech yang penting artinya dilihat dari sudut politik Internasional, karena menerima asas keseimbangan kekuatan sebagai asas politik internasional.

\section{E. Kesimpulan}

Terjadinya Reformasi Protestan di sebabkan faktor ekonomi, politik, nasionalisme, paham individualisme renaisans, dan keprihatinan yang sangat meningkat terhadap penyalahgunaan wewenang Gereja di Eropa.(yaitu salah satunya adanya praktek indulgensi).

Reformasi protestan menurut penulis mempunyai dampak positif dan negatif, dampak positifnya yaitu dengan adanya reformasi yang dilakukan oleh reformer dapat memperbaiki keterpurukan baik di Gereja sendiri, ekonomi masyarakat, politik dll. Adapun akibat negative dari reformasi protestan yaitu adanya perpecahan dan peperangan dalam agama Katolik, dimana Katolik pecah menjadi dua agama yaitu Katolik dan Protestan dan dalam perjalanan reformasi banyak terjadi peperangan dan perselisihan yang mengakibatkan pembunuhan di berbagai negara baik di Jerman, Prancis, Inggris.

Adapun bentuk perdamaian yang pernah dilakukan sepanjang perjalanan reformasi protestan antara yaitu dalam bentuk pisahnya agama Katolik menjadi dua yaitu Protestan dan Katolik dan dalam perpecahan ini diberikan kebebasan dalam menjalankan kepercayaannya masing-masing. Dan adanya perjanjian cuius region, eius religio (wilayahmu menentukan agama mu).

Peperangan yang terjadi di prancis antara katolik dan protestan yang melibatkan 16 negara yang dimulai tahun 1562 dan berakhir pada tahun 1598 . diakhiri dengan adanya kesepakatan atau perjanjian yang isinya memberikan kebebasan beragama bagi orang Protestan jaminan itu ditetapkan pada bulan 13 April 1598 dari raja Hanry IV di Prancis. Dan semua konflik antara protestan dan katolik diakhiri dengan perjanjian wesphalia, perjanjian ini merujuk dengan ditandatanganinya perjanjian mulai 19 Mei sampai 24 Oktober 1928 dan perdamaian ini mengakhiri peperangan baik 30 tahun maupun 80 tahun peperangan antara Katolik dan Protestan. Inti dari perjanjian itu antaralain: semua kelompok menerima 
perjanjian Augsbrug tahun 1555, bahwa setiap penguasa memiliki hak untuk menentukan agama negaranya, untuk memilih luteran, calvin, yuwingli. Dan oarang yang hidup di negara yang tempat hidupnya bukan sesuai dengan agamanya diberikan kebebasan untuk beribadah pada waktu yang telah ditentukan sesusi dengan ajaran Gereja. 


\section{DAFTAR PUSTAKA}

Alister E.Macgrath, Reformation Thought: An Introduction, Published by Blackwell Publishers, 1993, terj tim PT BPK Gunung Mulia, Jakarta, 1996.

Bahri Ghazali, Agama Masyarakat: Pengenalan Sejarah Agama-agama, Yogyakarta: Pustaka Fahima, 2005.

Charles Blitzer, Age of Kings,New York: Time Incorporated, 1967.

Edith Simon, The Reformation, New York: Time-Life Books, 1966.

Francois Furet dan Denis Richet, French Revolution, terj. Team Penerjemah Lembaga Indonesia Prancis, Yogyakarta: Gajah Mada University Press, 1989.

Hans-Peter Grosshans, Luther, terj P. Hardono Hadi, Yogyakarta: Kanisius, 2001.

Hans Kung, Theologi For The Third Millennium An Ecumenical View, translated by Peter Heinegg, united States Of America, 1988.

H. Byron Earhart, Religious Tradisions Of The Word: A Journey Through Africa, Nort America, Mesoamerica, Judalsm, Crhristianity, Hinduism, Buddhism, China And Japan, Hipersan Francisco. 1993.

Huston Smith, The Religions of Man, Perennial Library, Haper \& Row, Publisher, New York, Hargestown, San Francisco, London, tt, Terj, Saafroedin Bahar, Jakarta: Yayasan Obor, 2004, hlm. 403.

Karen Armstrong, The Battle For God, New York: Alfred A. Knopf, 2000, terj. Satriowahono dkk, Jakarta: Mizan, 2004.

Lee Cameron Mc Donald, Western Political Theory, Vol II, New York: Harcourt Brace Javanovich, 1969.

Marwati Djoened Poesponegoro, Tokoh dan Peristiwa dalam Sejarah Eropa Awal Masehi- 1815, Jakarta: Ul.Press, 1998.

Rodney Stark, One True God, terj. M.Sadat Ismail, Yogyakarta: Qalam, 2003.

Roland H. Bainton, The Age of Reformation, New Jersey: D. Van. Nostrand Company,Inc.,1956.

Stephen Tong, Reformasion And Teologi Reformer, tej. Ahmad suadi, Jakarta: Taman Pustaka Kristen, 1991.

Th. Sumartana, Sekelumit Sejarah Gereja Protestan, dalam Sejarah, Teologi dan Etika Agama-agama, Yogyakarta: Interfidei, 2003.

www. reformasi protestan.com di download tanggal 20 maret 2009. 
ISSN: 2443-0919

JIA/Juni 2019/Th. 20/no 1

http://perjanjian-westphalia-dan-munculnya-negara-bangsa/di download tanggal 23 April 2009.

http://perang-saudara-seagama-di-prancis di download tanggal 23 April 2009. 